九州大学学術情報リポジトリ

Kyushu University Institutional Repository

\title{
Effects of Addition of Glucose and Sorbic Acid on the Fermentationi Quality of Guineagrass(Panicum maximum Jacq.) Si lages
}

\section{Shao, Tao}

Visiting Research Scientist from Lanzhou Institute of Animal Science and Veterinary Medicine of CAAS | Research Student, School of Agriculture, Kyushu University | Research Student, School of Agriculture, Kyushu University

Oba, Noriko

Research Student, School of Agriculture, Kyushu University

Shimojo, Masataka

Research Student, School of Agriculture, Kyushu University

Masuda, Yasuhisa

Research Student, School of Agriculture, Kyushu University

https://doi.org/10.5109/4505

出版情報：九州大学大学院農学研究院紀要. 47 (2)，pp.351-358，2003-02-01. Faculty of Agriculture, Kyushu University

バージョン :

権利関係 : 


\title{
Effects of Addition of Glucose and Sorbic Acid on the Fermentation Quality of Guineagrass (Panicum maximum Jacq.) Silages
}

\author{
Tao SHAO $^{1}$, Noriko OHBA ${ }^{2}$, Masataka SHIMOJO and Yasuhisa MASUDA ${ }^{\dagger}$
}

\author{
Laboratory of Animal Feed Science, Division of Animal Science, Department of \\ Animal and Marine Bioresource Sciences, Faculty of Agriculture, \\ Kyushu University, Fukuoka \\ 812-8581, Japan
}

(Received October 31, 2002 and accepted November 7, 2002)

\begin{abstract}
This experiment was carried out to study the effects of adding glucose or sorbic acid or both on the fermentation quality and residual mono-and disaccharides compositions of guineagrass silages. Guineagrass was treated with glucose $(\mathrm{G})$ at the rates of $0,0.5,1.0$ and $2.0 \%$, with or without sorbic acid (S) at the rate of $0.1 \%$ on the fresh weight basis. After thorough mixing, the grass material was ensiled into a laboratory silo (1 liter capacity) in triplicates and kept at the ambient temperature of $25^{\circ} \mathrm{C}$, followed by being opened after 30 days of storage.

Except for the silage with no addition, all silages were well preserved as judged from their low AN/TN (35.88-77.51 g/kg) and no or only detectable level of BA, VA and PA. Adding S alone showed a small decrease in $\mathrm{pH}$ value, however, a significant increase in LA content and significant decreases in AN/TN and VFAs content as compared with control. These suggested that $\mathrm{S}$ alone was effective in inhibiting the growth of clostridial and other aerobic bacteria, and decreased the protein degradation and the production of BA and VFAs, whereas increased LA content. However, the improvement was smaller than the other treatments ( $G$ or $G$ with $S$ ), which was attributed to the low content of WSC in the original grass. All glucose addition silages (G or G with $\mathrm{S}$ ) largely improved the fermentation qualities, as indicated by significantly lower $\mathrm{pH}(3.78-4.25)$, AN/TN $(35.88-71.08 \mathrm{~g} / \mathrm{kg})$ and VFAs $(9.00-28.99 \mathrm{~g} / \mathrm{kg})$, and the absence of BA, VA and PA, whereas significantly higher LA (24.47-52.53 g/kg) and LA/AA (1.06-5.89), when compared with control. Increasing the rate of glucose addition resulted in further decreases in $\mathrm{pH}, \mathrm{AN} / \mathrm{TN}$ and VFAs and further increases in LA and LA/AA. There were not significant differences in the fermentation qualities between $2 \% \mathrm{G}$ and $1 \% \mathrm{G}$ and between $\mathrm{S}+$ $2 \% \mathrm{G}$ and $\mathrm{S}+1 \% \mathrm{G}$, respectively, except for a large decrease in AN/TN value and a slightly but significantly higher residual glucose and mono-and disaccharides when the G level was $2 \%$. Similarly, there were not significant differences in the fermentation qualities between $G$ alone and $\mathrm{G}$ with $\mathrm{S}$, however, $\mathrm{G}$ with $\mathrm{S}$ addition tended to decrease $\mathrm{AA}$ content and tended to increase LA content and LA/AA. Moreover, $\mathrm{S}+2 \% \mathrm{G}$ had slightly but significantly higher residual glucose and total mono-and disaccharides contents as well as significantly lower ethanol content compared with $2 \% \mathrm{G}$. These suggested that the $\mathrm{S}$ addition inhibited the aerobic bacterial growth and saved the fermentation substrates for LAB. From the present study, it was suggested that $1 \% \mathrm{G}$ or $\mathrm{S}+1 \% \mathrm{G}$ addition was effective for improving the fermentation quality of guineagrass silage.
\end{abstract}

\section{INTRODUCTION}

It is well known that tropical grasses are generally considered to be a particular chal-

1) Visiting Research Scientist from Lanzhou Institute of Animal Science and Veterinary Medicine of CAAS, Lanzhou Gansu Province of China

2) Research Student, School of Agriculture, Kyushu University

' † Corresponding Author (E-mail: ymasuda@agr.kyushu-u.ac.jp) 
lenge in silage making and this was attributable to two main factors: first, they tended to have low water soluble carbohydrate (WSC), secondly, there is an essential difference in the physical structure between temperate and tropical grasses; tropical grasses often have more porosity, coarseness and permeability than their temperate counterparts (Catchpoole and Henzell, 1971). When tropical grasses were ensiled, relatively large quantities of air may be trapped in the forage mass. This can result in more plant respiration and aerobic bacterial activity. Then, there occurs the use up of WSC which is normally required by desirable lactic acid bacteria (LAB) (Alli et al., 1985), causing fermentable substrates loss. Although the activity of aerobic bacteria could be restricted by proper ensiling, such as chopping, compaction of the forage mass in the silo and by rapid sealing of the silo after it has been filled. However, tropical grasses are usually more difficult to compress and exclude air completely (Catchpoole and Henzell, 1971). Therefore, it is necessary to use some additives to increase the supply of available substrates for the growth of $\mathrm{LAB}$ or to inhibit the activity of aerobic bacteria and decrease the loss of WSC in the early stage of ensilage. Glucose addition to the herbage is a way of increasing the amounts of fermentable substrate for the LAB (McDonald et al., 1991), and several researches have demonstrated the advantages of glucose as silage additive to improve the fermentation quality (Ohyama et al., 1971, 1973, 1975). Sorbic acid is commonly used as a mould inhibiter in foods, and has been reported to be effective in preventing mould growth (Deuel et al., 1954; Salunkhe, 1956; Lacey, 1989). In addition potassium sorbate has been shown to inhibit the growth of yeasts and mould and used as an ingredient of commercial silage additives (Alli and Baker, 1982; Cai and Ogawa, 1998; Hattori et al., 1996). Woolford (1975) also confirmed that sorbic acid had a strong inhibiting effect on the growth of yeasts and moulds. These researchers used sorbic acid as a silage additive to inhibit the aerobic deterioration, when the silo was opened and exposed to air during the utilization period. In the present study, we used sorbic acid in order to restrict the activity of aerobic bacteria during very early stage of ensiling and decrease the loss of WSC caused by the undesirable bacterial activity. There is, however, relatively little published information about the effects of sorbic acid on the silage fermentation quality, especially for tropical grasses.

The objective of the present study was to investigate the effects of the addition of glucose; sorbic acid or the combination of them on the fermentation quality and residual mono-and disaccharides compositions of guineagrass silages.

\section{MATERIALS AND METHODS}

\section{Silage making}

Guineagrass (Panicum maximum Jacq.) was cultivated in the experimental field of Kyushu University, Hakozaki, Fukuoka, Japan. The first growth of the guineagrass was hand-harvested with a sickle at the heading stage on August 10 in 2000. All the grass materials were immediately chopped into about $1 \mathrm{~cm}$ length prior to treatments. There were eight treatments in this experiment: Untreated (Control); Glucose $0.5 \%(0.5 \% \mathrm{G})$; Glucose 1.0\% (1\%G); Glucose 2.0\% (2\%G); Sorbic acid 0.1\% (S); S+0.5\%G; S+1\%G; $\mathrm{S}+2 \% \mathrm{G}$ on the fresh weight basis of guineagrass, respectively. After thorough mixing, a 650 -gram of the treated grass was ensiled into a laboratory silo (1 liter capacity) in 
triplicates. This was followed by being sealed with a screw top and kept at the ambient temperature of $25^{\circ} \mathrm{C}$, and all silos were opened after 30 days of storage.

\section{Chemical analyses}

The chopped grass was immediately collected for the determination of dry matter (DM), total nitrogen (TN), mono-and disaccharides (fructose, glucose and sucrose) and crude protein (CP). After the silo was opened and the contents were mixed thoroughly, a 60 -gram of sample was taken from each silo and a 120-gram of distilled water was added before being stored in the refrigerator at $4^{\circ} \mathrm{C}$ for 24 hours. Then, the material was filtered through a double-layered cheesecloth and a filter paper (Toyo No. 5A), and the filtrate was used for the determination of $\mathrm{pH}$, ammonia-N (AN), lactic acid (LA), ethanol and volatile fatty acids (VFAs). The $\mathrm{pH}$ of silage was measured using a glass electrode $\mathrm{pH}$ meter (Horiba Co, Japan). The LA was determined using the method of Barker and Summerson (1941), VFAs and ethanol with gas chromatography (Shimadzu GC-17A with $12 \mathrm{~m}$ capillary column, condition: column temperature $100^{\circ} \mathrm{C}$, injection temperature $250^{\circ} \mathrm{C}$ ). TN was determined by the Kjeldahl method (AOAC, 1984), and AN with an ammonia electrode (Model IM-22P, Toa Electronics Ltd, Japan), CP was determined with 6.25 multiplied by TN. The DM contents of the fresh material and silages were determined by drying in an oven at $80^{\circ} \mathrm{C}$ for at least 48 hours (AOAC, 1984), and DM of silage was recalculated by the contents of volatile components. Mono-and disaccharides compositions of the grass and silages were determined by high performance liquid chromatography as shown in our previous report (Shao et al., 2002).

\section{Statistical analyses}

All data were analyzed statistically by two-way analysis of variance with sorbic acid and glucose additive as main factors and Fisher's least significant difference test; these were performed by ANOVA using the GLM procedure of the Statistical Analysis System (SAS, 1984) and the significance was declared at $\mathrm{p}<0.05$.

\section{RESULTS}

The characteristics of initial guineagrass are presented in Table 1. It showed $230.58 \mathrm{~g} / \mathrm{kg}$ for DM, $76.18 \mathrm{~g} / \mathrm{kg}$ for crude protein, $20.29 \mathrm{~g} / \mathrm{kg}$ for fructose, $18.64 \mathrm{~g} / \mathrm{kg}$ for glucose, $17.44 \mathrm{~g} / \mathrm{kg}$ for sucrose and $56.37 \mathrm{~g} / \mathrm{kg}$ for total mono-and disaccharides.

The effects of additive treatments on the fermentation characteristics of guineagrass silages are presented in Table 2. Except for the control silage, all silages of additive treatments were well preserved as judged from their low value of AN/TN $(35.88-77.51 \mathrm{~g} / \mathrm{kg}$ ) and no or only detectable level of butyric acid (BA), which were lower than the concentration generally accepted for a well preserved silage that should have less than $2.0 \mathrm{~g} / \mathrm{kg}$ of

Table 1. Characteristics of guineagrass before being ensiled $\left(\mathrm{g} \mathrm{kg}^{-1} \mathrm{DM}\right)$

\begin{tabular}{cccccc}
\hline Dry matter $\left(\mathrm{g} \mathrm{kg}^{-1}\right)$ & Crude protein & Fructose & Glucose & Sucrose & Mono-and disaccharides \\
\hline 230.58 & 76.18 & 20.29 & 18.64 & 17.44 & 56.37 \\
\hline
\end{tabular}


Table 2. Fermentation quality of guineagrass silages treated with glucose or glucose with sorbic acid

\begin{tabular}{|c|c|c|c|c|}
\hline Item & Control & $0.5 \%$ Glucose & $1 \%$ Glucose & $2 \%$ Glucose \\
\hline $\mathrm{pH}(\mathrm{SD})$ & $4.56(0.22) \mathrm{c}^{1)}$ & $4.09(0.07) \mathrm{b}$ & $3.95(0.02) \mathrm{a}$ & $3.78(0.03) a$ \\
\hline $\mathrm{DM}(\mathrm{SD})\left(\mathrm{g} \mathrm{kg}^{-1}\right)$ & $218.86(4.92) \mathrm{a}$ & $221.53(4.28) \mathrm{a}$ & $233.13(7.64) b$ & 230.34 (11.68)ab \\
\hline Ethanol (SD) $\left(\mathrm{g} \mathrm{kg}^{-1} \mathrm{DM}\right)$ & $3.17(0.34) \mathrm{a}$ & $2.95(0.40) \mathrm{a}$ & $3.04(0.37) \mathrm{a}$ & $3.58(0.31) \mathrm{aB}$ \\
\hline $\mathrm{LA}(\mathrm{SD})\left(\mathrm{g} \mathrm{kg}^{-1} \mathrm{DM}\right)$ & $4.00(3.28) \mathrm{aA}^{2)}$ & $29.83(3.93) b$ & $45.47(18.76) b$ & $42.36(27.81) \mathrm{b}$ \\
\hline $\mathrm{AA}(\mathrm{SD})\left(\mathrm{g} \mathrm{kg}^{-1} \mathrm{DM}\right)$ & $16.62(5.08) \mathrm{a}$ & $28.21(9.34) \mathrm{bB}$ & 20.09 (11.99)ab & $13.56(3.52) \mathrm{a}$ \\
\hline $\mathrm{BA}$ (SD) $\left(\mathrm{g} \mathrm{kg}^{-1} \mathrm{DM}\right)$ & $12.86(7.16) \mathrm{bB}$ & $0.34(0.33) \mathrm{a}$ & $0.11(0.19) \mathrm{a}$ & $0.00(0.00) a$ \\
\hline VA (SD) $\left(\mathrm{g} \mathrm{kg}^{-1} \mathrm{DM}\right)$ & $0.33(0.30) \mathrm{bB}$ & $0.00(0.00) \mathrm{a}$ & $0.00(0.00) \mathrm{a}$ & $0.00(0.00) \mathrm{a}$ \\
\hline PA (SD) (g kg-1 DM) & $0.77(0.43) \mathrm{cB}$ & $0.44(3.84) \mathrm{bB}$ & $0.00(0.00) \mathrm{a}$ & $0.00(0.00) \mathrm{a}$ \\
\hline VFAs (SD) $\left(\mathrm{g} \mathrm{kg}^{-1} \mathrm{DM}\right)$ & $30.58(4.12) \mathrm{bB}$ & $28.99(9.12) \mathrm{bB}$ & $20.20(11.53) \mathrm{ab}$ & $13.56(3.64) \mathrm{a}$ \\
\hline $\mathrm{LA} / \mathrm{AA}(\mathrm{SD})$ & $0.24(0.4) \mathrm{a}$ & $1.06(0.14) \mathrm{b}$ & $2.26(1.71) \mathrm{c}$ & $3.12(2.55) \mathrm{c}$ \\
\hline AN (SD) $\left(\mathrm{g} \mathrm{kg}^{-1} \mathrm{TN}\right)$ & $109.1(14.90) \mathrm{cB}$ & $71.08(1.50) \mathrm{b}$ & $59.47(5.65) \mathrm{b}$ & $35.92(4.77) \mathrm{a}$ \\
\hline Item & $\begin{array}{l}\text { Control+ } \\
0.1 \% \text { Sorbic acid }\end{array}$ & $\begin{array}{l}0.5 \% \text { Glucose }+ \\
0.1 \% \text { Sorbic acid }\end{array}$ & $\begin{array}{c}1 \% \text { Glucose }+ \\
0.1 \% \text { Sorbic acid }\end{array}$ & $\begin{array}{l}2 \% \text { Glucose }+ \\
0.1 \% \text { Sorbic acid }\end{array}$ \\
\hline $\mathrm{pH}(\mathrm{SD})$ & $4.42(0.05) \mathrm{c}$ & $4.25(0.06) \mathrm{b}$ & $3.95(0.06) \mathrm{ab}$ & $3.87(0.10) \mathrm{a}$ \\
\hline $\mathrm{DM}(\mathrm{SD})\left(\mathrm{g} \mathrm{kg}^{-1}\right)$ & $220.86(4.74) \mathrm{a}$ & $223.53(4.08) \mathrm{ab}$ & $228.76(1.53) \mathrm{ab}$ & $231.36(8.53) \mathrm{b}$ \\
\hline Ethanol (SD) (g kg-1DM) & $3.15(0.30) \mathrm{a}$ & $3.05(0.34) \mathrm{a}$ & $3.17(0.30) \mathrm{a}$ & $2.96(0.21) \mathrm{aA}$ \\
\hline LA (SD) $\left(\mathrm{g} \mathrm{kg}^{-1} \mathrm{DM}\right)$ & $18.02(5.24) \mathrm{aB}$ & 24.47 (10.07)a & $49.52(9.67) b$ & $52.53(38.99) \mathrm{b}$ \\
\hline $\mathrm{AA}(\mathrm{SD})\left(\mathrm{g} \mathrm{kg}^{-1} \mathrm{DM}\right)$ & $19.22(4.37) \mathrm{b}$ & $14.99(1.44) \mathrm{aA}$ & $12.10(3.62) \mathrm{a}$ & $8.92(0.44) \mathrm{a}$ \\
\hline $\mathrm{BA}$ (SD) $\left(\mathrm{g} \mathrm{kg}^{-1} \mathrm{DM}\right)$ & $0.10(0.18) \mathrm{aA}$ & $0.00(0.00) \mathrm{a}$ & $0.00(0.00) \mathrm{a}$ & $0.08(0.13) \mathrm{a}$ \\
\hline VA (SD) $\left(\mathrm{g} \mathrm{kg}^{-1} \mathrm{DM}\right)$ & $0.00(0.00) \mathrm{aA}$ & $0.00(0.00) \mathrm{a}$ & $0.00(0.00) \mathrm{a}$ & $0.00(0.00) \mathrm{a}$ \\
\hline $\mathrm{PA}(\mathrm{SD})\left(\mathrm{g} \mathrm{kg}^{-1} \mathrm{DM}\right)$ & $0.00(0.00) \mathrm{aA}$ & $0.00(0.00) \mathrm{aA}$ & $0.00(0.00) \mathrm{a}$ & $0.00(0.00) a$ \\
\hline VFAs (SD) (g kg-1DM) & $19.32(4.21) \mathrm{bA}$ & $14.99(2.10) \mathrm{aA}$ & $12.10(3.81) \mathrm{a}$ & $9.00(0.44) \mathrm{a}$ \\
\hline $\mathrm{LA} / \mathrm{AA}(\mathrm{SD})$ & $0.94(0.08) a$ & $1.63(0.24) \mathrm{a}$ & $4.09(1.21) \mathrm{b}$ & $5.89(4.45) \mathrm{b}$ \\
\hline $\mathrm{AN}$ (SD) $\left(\mathrm{g} \mathrm{kg}^{-1} \mathrm{TN}\right)$ & $77.51(13.24) \mathrm{cA}$ & $58.20(16.07) \mathrm{b}$ & $46.72(6.69) \mathrm{ab}$ & $35.88(4.55) \mathrm{a}$ \\
\hline
\end{tabular}

1) Values followed by different small letters in the same row show significant differences at $P<0.05$.

2) Values followed by different large letters in the same item with and without sorbic acid show significant differences at $\mathrm{P}<0.05$.

BA and less than $80.0 \mathrm{~g} / \mathrm{kg}$ of AN/TN (Henderson, 1993).

The addition of $\mathrm{S}$ alone showed a slight decrease in $\mathrm{pH}$ value but there was a significant high LA content and significant low values of VFAs and AN/TN as compared with the control silage, and also showed an absence of BA, valeric acid (VA) and propionic acid (PA). The contents of acetic acid (AA), ethanol and DM did not show significant differences between the control and $\mathrm{S}$. However, $\mathrm{S}$ alone showed a higher tendency in LA/AA than control.

The addition of G alone significantly decreased $\mathrm{pH}$ and AN/TN, whereas significantly increased LA/AA and LA content. The ethanol content did not show significant differences among all rates of $\mathrm{G}$ addition. The content of AA increased significantly in $0.5 \% \mathrm{G}$, but did not show significant differences among control, $1 \% \mathrm{G}$ and $2 \% \mathrm{G}$. No or very small amounts of BA, VA and PA were detected in all silages of $\mathrm{G}$ addition alone. The addition of $1 \% \mathrm{G}$ further decreased $\mathrm{pH}$ and $\mathrm{AN} / \mathrm{TN}$, and increased LA/AA and LA content as compared with $0.5 \% \mathrm{G}$ addition. There were not significant differences in the fermentation qualities between $1 \% \mathrm{G}$ and $2 \% \mathrm{G}$, except for AN/TN.

In the combined treatments of $\mathrm{G}$ and $\mathrm{S}$, adding $\mathrm{S}+1 \% \mathrm{G}$ and $\mathrm{S}+2 \% \mathrm{G}$ significantly decreased $\mathrm{pH}, \mathrm{AN} / \mathrm{TN}$ and AA content, whereas significantly increased LA/AA and LA 
Table 3. The residual mono-and disaccharides compositions of guineagrass silages treated with glucose or glucose with sorbic acid $\left(\mathrm{g} \mathrm{kg}^{-1}\right)$

\begin{tabular}{|c|c|c|c|c|}
\hline Item & Control & $0.5 \%$ Glucose & $1 \%$ Glucose & $2 \%$ Glucose \\
\hline Fructose (SD) & $0.39(0.03) \mathrm{a}$ & $0.37(0.02) \mathrm{a}$ & $0.36(0.01) a$ & $0.24(0.12) \mathrm{a}^{1)} \mathrm{A}^{2)}$ \\
\hline Glucose (SD) & $0.17(0.01) \mathrm{a}$ & $0.18(0.01) a$ & $0.20(0.03) \mathrm{a}$ & $1.01(0.20) \mathrm{bA}$ \\
\hline Sucrose (SD) & $0.24(0.04) \mathrm{a}$ & $0.22(0.01) \mathrm{a}$ & $0.12(0.08) a$ & $0.17(0.08) \mathrm{a}$ \\
\hline Mono-and disaccharides (SD) & $0.80(0.04) a$ & $0.77(0.01) \mathrm{a}$ & $0.68(0.07) \mathrm{a}$ & $1.42(0.21) \mathrm{aA}$ \\
\hline Item & $\begin{array}{l}\text { Control+ } \\
0.1 \% \text { Sorbic acid }\end{array}$ & $\begin{array}{l}0.5 \% \text { Glucose }+ \\
0.1 \% \text { Sorbic acid }\end{array}$ & $\begin{array}{c}1 \% \text { Glucose }+ \\
0.1 \% \text { Sorbic acid }\end{array}$ & $\begin{array}{l}2 \% \text { Glucose }+ \\
0.1 \% \text { Sorbic acid }\end{array}$ \\
\hline Fructose (SD) & $0.38(0.01) \mathrm{a}$ & $0.36(0.01) \mathrm{a}$ & $0.37(0.02) \mathrm{a}$ & $0.72(0.51) \mathrm{aB}$ \\
\hline Glucose (SD) & $0.18(0.02) \mathrm{a}$ & $0.23(0.07) \mathrm{a}$ & $0.38(0.02) \mathrm{a}$ & $2.92(3.03) \mathrm{bB}$ \\
\hline Sucrose (SD) & $0.21(0.01) \mathrm{a}$ & $0.09(0.06) \mathrm{a}$ & $0.08(0.08) \mathrm{a}$ & $0.08(0.01) \mathrm{a}$ \\
\hline Mono-and disaccharides (SD) & $0.77(0.01) \mathrm{a}$ & $0.68(0.07) a$ & $0.83(0.02) \mathrm{a}$ & $3.72(2.77) \mathrm{bB}$ \\
\hline
\end{tabular}

1) Values followed by different small letters in the same row show significant differences at $P<0.05$.

2) Values followed by different large letters in the same item with and without sorbic acid show significant differences at $\mathrm{P}<0.05$.

content as compared with the $\mathrm{S}$ addition. However, the improvement in the fermentation quality was smaller when $\mathrm{S}+0.5 \% \mathrm{G}$ was added. Further addition of glucose tended to decrease the contents of $\mathrm{AA}$ and VFAs, and the value of $\mathrm{pH}$ and $\mathrm{AN} / \mathrm{TN}$, whereas increased LA/AA, LA content as compared with $\mathrm{S}+0.5 \% \mathrm{G}$. There were no significant differences in the fermentation qualities between $\mathrm{S}+1 \% \mathrm{G}$ and $\mathrm{S}+2 \% \mathrm{G}$ additions. However, the addition of $\mathrm{S}+2 \% \mathrm{G}$ further increased DM content and decreased AN/TN as compared with $\mathrm{S}+1 \% \mathrm{G}$. Almost no amounts of $\mathrm{BA}$, VA and PA were detected in silages of $\mathrm{S}$ and $\mathrm{G}$ combination treatments.

There were not large differences in the fermentation qualities between $G$ alone and the combination of $\mathrm{G}$ and $\mathrm{S}$. However, $0.5 \% \mathrm{G}$ addition had significantly higher contents of $\mathrm{AA}$ and VFAs than $\mathrm{S}+0.5 \% \mathrm{G}$, and $\mathrm{S}+2 \% \mathrm{G}$ addition showed a slightly but significantly lower ethanol content as compared with $2 \% \mathrm{G}$ silage. The combination of $\mathrm{G}$ and $\mathrm{S}$ tended to decrease the contents of AA and VFAs.

The contents of residual mono-and disaccharides (fructose, glucose, sucrose) are shown in Table 3. Except for $2 \% \mathrm{G}$ and $\mathrm{S}+2 \% \mathrm{G}$, there were very little amounts of residual mono-and disaccharides in silages. Adding $2 \% \mathrm{G}$ showed a slightly but significantly higher residual glucose among the treatments with $\mathrm{G}$. Similarly, $2 \% \mathrm{G}+\mathrm{S}$ also showed a slightly but significantly higher residual glucose and total mono-and disaccharides among the combination treatments with $\mathrm{G}$ and $\mathrm{S}$. Furthermore, adding $2 \% \mathrm{G}+\mathrm{S}$ had a slightly but significantly higher residual glucose and total mono-and disaccharides than $2 \% \mathrm{G}$ addition.

\section{DISCUSSION}

In the present experiment, $\mathrm{S}$ addition properly improved the silage fermentation quality with markedly lower AN/TN, VFAs, and almost no amounts of BA, VA and PA contents and markedly higher LA content as compared with the control silage. This suggested that the addition of $\mathrm{S}$ depressed the growth of clostridia or other aerobic 
bacteria (yeast and mould), and thus inhibited the protein degradation and the production of BA and VFAs by undesirable bacteria during ensiling. This was contrarily reflected in the control silage that had significantly higher value of AN/TN and contents of $\mathrm{BA}$ and VFAs. These results are in agreement with the previous reports by Alli et al. (1985), Weinberg et al. $(1988,1989)$ and Barbara et al. (1990). However, S alone showed a small reduction in $\mathrm{pH}$ value, and smaller improvement than the other treatments ( $\mathrm{G}$ or $\mathrm{G}$ with $\mathrm{S}$ additions). This may be explained as follows; although $\mathrm{S}$ alone probably inhibited the activity of the undesirable bacteria with the result of decreasing the consumption of WSC, the fermentation substrates $(56.37 \mathrm{~g} / \mathrm{kg}$ ) were still not enough to allow the epiphytic LAB to produce more LA to decrease the final $\mathrm{pH}$ value further (Ridla and Uchida, 1998; Tamada et al., 1996).

Evidences have also shown that the lack of fermentable substrates may be primarily responsible for the unstable preservation of tropical grass silages (Catchpoole and Henzell, 1971; Crowder and Chheda, 1982). Additives to fortify sugars can therefore be a great help to increase the storability (Uchida and Kitamura, 1987; Kim and Uchida, 1991). In the present experiment, $\mathrm{G}$ alone or $\mathrm{G}$ with $\mathrm{S}$ successsully improved the fermentation quality even at the lowest rate of $0.5 \% \mathrm{G}$ addition, where there were larger decreases in the value of $\mathrm{pH}$ and AN/TN and increases in LA/AA and LA content with no or only detectable level of BA, VA, PA as compared with the control and S. These suggested that glucose additive is of particular benefit when applied to such grasses of low WSC as guineagrass. The increasing rate of glucose addition results in further decreases in $\mathrm{pH}$, AN/TN and AA, and increases in LA and LA/AA. This suggested that high rates of glucose addition stimulated further the activity of homofermentative $\mathrm{LAB}$, and increased the rate and extent of reduction in $\mathrm{pH}$ and production of LA during the early stage of ensiling through inhibiting the proteolysis and improving the stability of amino acids. These results are in agreement with the data of Ohyama et al. $(1971,1975)$.

Except for AN/TN, there were not great differences in the fermentation qualities between $1 \% \mathrm{G}$ and $2 \% \mathrm{G}$ and between $\mathrm{S}+1 \% \mathrm{G}$ and $\mathrm{S}+2 \% \mathrm{G}$, respectively. These could be explained as follows; $1 \%$ glucose addition was enough for epiphytic LAB to produce the sufficient LA for the good quality silage with low $\mathrm{pH}$. This was also reflected in both $2 \% \mathrm{G}$ and $\mathrm{S}+2 \% \mathrm{G}$ additions that showed a slightly but significantly higher residual glucose content as compared with $1 \% \mathrm{G}$ and $\mathrm{S}+1 \% \mathrm{G}$, respectively. However, the addition of $2 \% \mathrm{G}$ and $\mathrm{S}+2 \% \mathrm{G}$ largely decreased AN/TN as compared with $1 \% \mathrm{G}$ and $\mathrm{S}+1 \% \mathrm{G}$, suggesting that higher level of glucose addition resulted in more rapid fall of $\mathrm{pH}$. This partially inhibited the activity of proteolysis by plant enzymes and possible aerobic bacterial deamination of amino acids, and improved the stability of amino acids in the early stage of ensiling (Kung et al., 1990).

In addition there were not great differences in fermentation qualities between $\mathrm{G}$ alone and $\mathrm{G}$ with $\mathrm{S}$. This indicated that the rate of $0.1 \%$ sorbic acid addition was adequate and effective because of no decrease in the activity of $\mathrm{LAB}$ with $\mathrm{S}$ addition. These results are in line with the data of Hattori et al. (1996) and Weinberg et al. (1989). They studied the concentration of sorbic acid in controlling the aerobic deterioration of corn silage or in the effects on orange peels fermentation quality. It was well documented that $0.1 \%$ sorbic acid addition was effective in inhibiting the activity of yeast, mould and aerobic acid bacteria, but did not inhibit the activity of LAB. In addition there was an indication that 
$\mathrm{S}+2 \% \mathrm{G}$ had higher residual glucose and total mono-and disaccharides contents and lower ethanol content than $2 \% \mathrm{G}$. The increase in residual WSC content in the silage as a result of sorbic acid addition has also been reported in some studies (Weinberg et al., 1988, 1989; Alli et al., 1985), which indicated that the sorbic acid inhibited the aerobic bacteria growth (mould or yeast) and saved the fermentation substrates for LAB.

In conclusion, based on the present study, both sorbic acid and glucose additions had a beneficial effect on the fermentation quality of guineagrass silage. There were not great differences in the fermentation quality between $1 \% \mathrm{G}$ and $2 \% \mathrm{G}$ and between $\mathrm{S}+1 \% \mathrm{G}$ and $\mathrm{S}+2 \% \mathrm{G}$, therefore additions of $1 \% \mathrm{G}$ and $\mathrm{S}+1 \% \mathrm{G}$ may be recommended.

\section{REFERENCES}

Alli, I. and B. E. Baker 1982 Effects of additives on lactic acid production and water soluble carbohydrates in chopped corn and alfalfa. J. Dairy Sci., 65: 1472-1478

Alli, I., S. Pabari, R. Fairbairn and B. E. Baker 1985 The effects of sorbates on the ensilage of chopped whole-plant maize and lucerne. J. Sci. Food Agric., 36: 63-70

AOAC 1984 Official Methods of Analysis. Association of Official and Analytical Chemists 14 th ed. Arlington, Virginia, USA

Barbara, M. L., A. F. Graham, S. M. George and D. Brown 1990 The combined effect of incubation temperature, $\mathrm{pH}$ and sorbic acid on the probability of growth of non-proteolytic, type B Clostridium botulinum. J. Appl. Bacteriol., 69: 481-492

Barker, S. B. and W. H. Summerson 1941 The colorimetric determination of lactic acid in biological material. J. Biol. Chem., 138: 535-554

Cai, Y. and M. Ogawa 1998 Effect of ammonium tetraformate on the aerobic deterioration of corn silage. J. Japan. Grassl. Sci., 44: 90-92

Catchpoole, V. R. and E. F. Henzell 1971 Silage and silage making from tropical herbage species. Herb. Abstr., 41: 213-221

Crowder, L. V. and H. R. Chheda 1982 Tropical grassland husbandry. Longman Group Limited, New York., pp. 316-323

Deuel, H. J. Jr., R. Alfin-Slater, C. S. Weil and H. F. Jr. Smyth 1954 Sorbic acid as a fungistatic agent for foods. I. Harmlessness of sorbic acid as a dietary component. Food Res., 19: 1-12

Hattori, I., S. Kumai and R. Fukumi 1996 Concentration of caproic and sorbic acids effective for inhibition of aerobic deterioration. Anim. Sci. Technol. (Jpn), 67: 1101-1109

Henderson, N. 1993 Silage additives. Anim. Feed Sci. Technol., 45: 35-56

Kim, K. H. and S. Uchida 1991 Comparative studies of ensiling characteristics between temperate and tropical species. 3. The effects of addition of glucose and formic acid on fermentation and proteolysis during ensilage. J. Japan. Grassl. Sci., 37: 253-260

Kung, L. Jr., B. R. Carmean and R. S. Tung 1990 Microbical inoculation or cellulase enzyme treatment of barley and vetch silage harvested at three maturities. J. Dairy Sci., 73: 1304-1311

Lacey, J. 1989 Pre-and post-harvest ecology of fungi causing spoilage of foods and other stored products. J. Appl. Bacteriol. Symp. Suppl., 11s-25s

McDonald, P., A. R. Henderson and S. J. E. Heron 1991 The Biochemistry of Silage. 2 nd ed. Cambrian Printers Ltd., Aberystwyth., pp. 184-236

Ohyama, Y., S. Masaki, A. Takigawa and T. Morichi 1971 Studies on various factors affecting silage fermentation. IX. Synergestic effect of inoculation of Lactobacillus plantarum and addition of glucose on silage quality. Jap. J. Zootech. Sci., 42: 1-8

Ohyama, Y., S. Masaki and T. Morichi 1973 Effects of temperature and glucose addition on the process of silage fermentation. Jap. J. Zootech. Sci., 44: 59-67

Ohyama, Y., T. Morichi and S. Masaki 1975 The effect of inoculation with Lactobacillus plantarum and the addition of glucose at ensiling on the quality of aerated silages. J. Sci. Food Agric., 26: 1001-1008

Ridla, M. and S. Uchida 1998 Effects of combined treatment of lactic acid bacteria and cell wall degrad- 
ing enzymes on fermentation and composition of rhodesgrass (Chloris gayana kunth.) silage. Asian-Aust. J. Anim. Sci., 11: 522-529

Salunkhe, K. 1956 Possible use of sorbic acid as a preservative for corn silage. Nature, 178:187

SAS Institute Inc. 1984 SAS/STAT User's Guide: Version 6. 4th ed. SAS Institute Inc., Cary, North Carolina

Shao, T., N. Ohba, M. Shimojo and Y. Masuda 2002 Dynamics of early fermentation of Italian ryegrass (Lolium multiflorum Lam.) silage. Asian-Aust. J. Anim. Sci., 15: 1606-1610

Tamada, J., H. Yokota, M. Oshima and I. Choi 1996 Effect of application of cellulase and lactic acid bacteria inoculant on the fermentation quality of napier grass (Pennisetum purpureum Schum.) silage. Proc. 8 th AAAP Anim. Sci. Congr. Jap. Soc. Zootech. Sci. Tokyo Japan. Vol. 2, pp. 256-257

Uchida, S. and Y. Kitamura 1987 Silage making from tropical pasture plants grown in south western islands of Japan. 1. Effect of various treatments at the ensiling time on quality of rhodesgrass and napiergrass silages. J. Japan. Grassl. Sci., 32: 369-374

Weinberg, Z. G., G. Pahlow, B. Dinter and G. Ashbell 1988 The effect of treatment with urea, sorbic acid, or dehydration on orange peel silage. Anim. Feed Sci. Technol., 20: 335-342

Weinberg, Z. G., G. Ashbell and B. Horev 1989 The effect of sorbic acid on loss reduction during storage of orange peels. J. Sci. Food Agric., 46: 253-258

Woolford, M. K. 1975 Microbiological screening of food preservation, cold sterilants and specific antimicrobial agents as potential silage additives. J. Sci. Food Agric., 26: 229-237 